\title{
Sources of Business Growth at Different Levels of Innovativeness: Case of Firms in $E U$ Countries
}

\author{
Ljiljana Božić \\ The Institute of Economics, Croatia \\ ljbozic@eizg.hr
}

The purpose of this research is to explore how investment in $\mathrm{R} \& \mathrm{D}$, training of employees, branding and reputation, design and acquisition of technology affect business performance measured in terms of turnover growth in firms operating in $\mathrm{EU}$ countries at different levels of innovation performance. This study contributes to the literature by identifying activities that lead to business growth of firms in less innovative countries for which R \& D is less relevant. Empirical part of the paper relies on survey data from Flash Eurobarometer 433 (European Commission 2016). Research findings reveal rather complex story behind business growth of firms across $\mathrm{E} U$ countries. Impact of $\mathrm{R} \& \mathrm{D}$ on business growth indeed varies across E U countries at different levels of innovativeness. In countries at lower level of innovativeness business growth relies on training of employees, branding and reputation as well as acquisition of new technologies.

Key Words: R\&D, training, branding, acquisition of technology, design

JEL Classification: M20, 030

https://doi.org/10.26493/1854-6935.18.127-145

\section{Introduction}

When it comes to achieving and maintaining good business performance and business growth, $\mathrm{R} \& \mathrm{D}$ remains one of the most important and widely recognized activities. Literature on innovation provides rich evidence on benefits of investing in $\mathrm{R} \& \mathrm{D}$. E U countries are still at different levels of innovation performance ranging from modest to lead innovators (see European Innovation Scoreboard). For several years consecutively EU countries ranked among modest and moderate innovators in the European Innovation Scoreboard (indicating rather low overall innovation performance) show rather sluggish progress insufficient for catching up with other countries. Technology gap between new and old EU member states, although somewhat reduced, remains rather considerable (Filippetti and Peyrache 2013). The progress has been slowed down during the latest eco- 
nomic crisis that affected more strongly innovation investment in catchup E U countries (Archibugi and Filippetti 2011; Makrevska Disoska et al. 2018). In addition to overall lack of $R \& D$, East European countries are, in general, inefficient when it comes to converting R\&D into productivity (Kravtsova and Radošević 2012).

Although $\mathrm{R} \& \mathrm{D}$ is generally considered a prerequisite to business growth, evidence shows it is more important for leader firms, i.e. firms closer to technology frontier ${ }^{1}$ (Coad 2008) that are, in general, more prone to innovation (Gombau and Segarra-Blasco 2011). Interaction of innovation, competition and technology on firm level is affected by development of economy and the level of technology of the country (Alder 2010). Growth in emerging economies where $\mathrm{R} \& \mathrm{D}$ expenditures as well as returns on $\mathrm{R} \& \mathrm{D}$ are low is generated by high number of imitators who create competition and supply (Minniti and Lévesque 2010).

Considering these findings, R\&D in technologically less advanced economies is not necessarily a generator of business growth. It is, therefore, hypothesized that firms in countries at lower level of innovativeness lack pressure to invest in $\mathrm{R} \& \mathrm{D}$ and consequently seek other paths to business growth. Acemoglu, Aghion, and Ziliboti (2006) show that importance of innovation relative to copying and adoption of existing technologies for productivity growth is higher for firms in countries closer to world technology frontier. However, Autant-Bernard et al. (2010) found that $\mathrm{EU}$ countries with low innovation capacity demonstrate weak adoption capacity as well.

Both academic literature and business practice recognize concepts and mechanisms other than $\mathrm{R} \& \mathrm{D}$, that contribute to achieving superior business performance such as firm reputation and branding, quality of human capital, and design of products and services. We still lack evidence on other activities that potentially can help firms in these countries to improve their business results. This research connects literature on business performance determinants and distance to frontier theory and aims to contribute to the literature by identifying activities that lead to business growth of firms in less innovative $\mathrm{EU}$ countries in comparison to firms in EU countries at higher levels of innovation performance. $28 \mathrm{EU}$ countries $^{2}$ are grouped according to innovativeness as defined by European Innovation Scoreboard 2017. ${ }^{3}$

The rest of the paper is organized as follows. Succeeding introductory section, in the second section a background literature is provided. The third section explains methodology and descriptive statistics. The fourth 
section covers results and discussion while the fifth section provides concluding remarks.

\section{Background Literature}

The importance of $\mathrm{R} \& \mathrm{D}$ for achieving outstanding business results is well emphasized in the literature. Research findings show that $R \& D$ is crucial for long term survival and growth (Siepel, Cowling, and Coad 2015) and it has positive effects on future cash flows and market value (Chauvin and Hirschey 1993). Relationship between R\&D expenditures and firm performance is somewhat more pronounced in manufacturing than in service sector (Ehie and Olibe 2010). Chen et al. (2016) show that manufacturing firms, especially those in electronics sector, benefit more from $R \& D$ investment in terms of business performance than service firms.

Wakelin (2001) argue that returns to R\&D are influenced by innovation history of the firm as well as innovation history of the sector. Betterperforming firms are likely to invest more in R \& D (Cainelli, Evangelista, and Savona 2006; Mansury and Love 2008). They can afford continuous $\mathrm{R} \& \mathrm{D}$ engagement and sufficient funding for these activities that surely helps them to continue their growth. According to García-Quevedo, Pellegrino, and Vivarelli (2014) investment in R\&D shows high level of persistence over time, especially in mature, well established firms.

Relationship between R\&D and productivity has attracted great attention (for extensive review see Hall, Mairesse, and Mohnen (2010) and Mohnen and Hall (2013)). Productivity growth is especially evident in firms with long history of R\&D investment (Hall and Mairesse 1995). Bond and Guceri (2017) found that productivity in enterprises that invest in $R \& D$ is on average 14 percent higher than in those with no $R \& D$. When it comes to returns to $\mathrm{R} \& \mathrm{D}$ investment, they are generally positive and higher than returns to ordinary capital (Hall, Mairesse, and Mohnen 2010). In-house R\&D contributes greatly to productivity in firms with low productivity level (Segarra Blasco and Teruel Carrizosa 2008). In young firms, R\&D is more important in terms of sales growth, while in large firms it leads to the labour productivity growth (Coad, Segarra, and Teruel 2016).

$\mathrm{R} \& \mathrm{D}$ is also important in terms of learning and technology adoption. In Cohen and Leventhal's (1990) model, investment in R\&D strengthens absorptive capacity and enables organizational learning. In countries further from technology frontier R \& D investment improves ability to apply and exploit technologies developed at the frontier (Madsen, Islam, and 
Ang 2010). Firms that rely on adoption of new technologies are more likely to grow but are not more productive (Koellinger 2008). Research results indicate that large investments in equipment lead to decline in productivity growth on a plant level (Huggett and Ospina 2001). New technology adoption often generates high costs as a result of lost output due to installation, replacement of complementary equipment and training of employees (Hall and Khan 2003).

Firms' effort to improve their business performance (in general or by $\mathrm{R} \& \mathrm{D}$ and acquisition of new technologies) is often accompanied by improving employees' skills through various training programmes. Research findings show that some firms never invest in $\mathrm{R} \& \mathrm{D}$ due to lack of knowledge inside the firm (Cuervo-Cazurra and Un 2010). Modifications of technologies, their adoption from external sources or even imitations are less demanding in terms of necessary skills and capabilities than development of radically new innovations and technologies.

Existing literature also suggests positive effects of human capital that occur through enabling innovation and R\&D. Human capital has positive effects on innovation development (Vivarelli 2014; Dakhli and De Clercq 2004) and enables firms to overcome innovation barriers (D'Este, Rentocchini, and Vega-Jurado 2014). Skills of the employees in firm are important for profiting from $\mathrm{R} \& \mathrm{D}$ investment (Leiponen 2005). Moreover, adoption of new technologies also requires adequate skills. It is often accompanied by training of employees that increases probability of improving firm productivity (Boothby, Dufour, and Tang 2010). Bartel and Lichtenberg (1987) argue that government programmes designed to encourage education will stimulate adoption and implementation of new technologies in firms. Improvement of employee skills through adequate education and training is likely to increase R\&D investment (Piva and Vivarelli 2009).

Apart from its importance for both innovation and adoption of new technologies, human capital is one of the most important factors that enable business growth (Haber and Reichel 2007). In fact, in Central and East European countries human capital, unlike R\&D, contributes to productivity growth (Kutan and Yigit 2009). Outcomes of investment in human capital are highly important for achieving success (Unger et al. 2011). According to Goldin and Katz (2008), higher level of education is related to labour productivity increase. ${ }^{4}$ Technological and scientific progresses, as well as social and business changes nowadays impose need for continuous training and education in order to develop and improve knowledge, 
skills and competences gained through formal education. Therefore, it is expected that investment in training of employees will contribute to achieving better business results.

From the perspective of marketing literature, one of the most important resources a firm can have is brand equity (Keller 1993; Aaker 1992). Brand equity positively affects market performance and profitability (Baldauf, Cravens, and Binder 2003). Firms that have strong brands show higher profitability (Yeung and Ramasamy 2008). Branding is imperative for business-to-consumer firms, but research results show that investment in brand development pays off for business-to-business (в 2 в) firms as well. Brand awareness is associated with market performance of firms operating on в 2 в market (Homburg, Klarmann, and Schmitt 2010) and strong brands contribute to business growth of в 2 в small and medium sized enterprises (Hirvonen, Laukkanen, and Salo 2016). Positive effects of strong brand on business performance are found by Wong and Merrilees (2008). Even though brand represents important component of intangible assets, firms rarely develop brand metric systems that would enable them to assess contribution of brand to their business performance (Munoz and Kumar 2004).

Investment in design and design management has positive contribution to firm performance (Chiva and Alegre 2009). It leads to higher labour productivity and total factor productivity (Cereda et al. 2005). Design is recognized as driver of market success due to its potential to attract customers' attention and provide additional value to the entire experience of product use (Bloch 1995). Unique features of products (including design) are one of the most important success factors (Cooper and Kleinschmidt 1987). Moreover, design can be used as strategic tool for achieving sustainable competitive advantage in the market (Kotler and Rath 1984).

Livesey and Moultrie (2009) distinguish between design in the creation of products and services and design in promoting products or the company. Design in the creation of products and services refers to technical aspects and design of the user experience. Design in promoting products or the company incorporate design of advertising and promotional activities for specific products and services and design as part of developing, promoting, and communicating the corporate identity. The role of design has changed over time and nowadays it has different roles in new product development (Perks, Cooper, and Jones 2005). It is worth to distinguish design activities that are incorporated in new product de- 
velopment (and related to product innovation) from changes in design of existing products (that are often characterized as marketing innovations). Regardless of the type, design has potential to improve overall business results. Design contributes to higher sale of new products and product innovation especially in large firms that use it throughout the development process (Roper et al. 2016). It is estimated that firms who rely on design throughout idea development, production as well as marketing and commercialization achieve the highest turnover growth rates in comparison to those who use it in one or two stages (Nevado, Barata, and Almendra 2016).

The above-cited literature testifies benefits generated by $\mathrm{R} \& \mathrm{D}$, acquisition of technology, but also training, branding and design for various aspects of business performance. The remainder of the paper explores how these activities affect business growth at different levels of innovativeness. Considering extant findings from distance to frontier literature, it is expected that gains will depend on the overall innovation performance of the countries.

\section{Methodology and Descriptive Statistics}

\section{METHODOLOGY}

The empirical research relies on survey data from Flash Eurobarometer 433 (European Commission 2016) survey available in GESIS Data Archive. This survey covers responses of micro, SMEs, and large firms in manufacturing, services (including retail) and industry in EU countries.

Dependent variable in all models is turnover growth in three-year period (from 2013 to 2015). Respondents reported if their turnover in the analysed period have fallen by more than 25 percent, fallen by between 5 and 25 percent, remained approximately the same, risen by between 5 and 25 percent or risen by more than 25 percent. Considering the type of dependent variable, empirical analysis relies on ordered probit model.

Independent variables take value 1 if firms invested in $\mathrm{R} \& \mathrm{D}$, acquisition of technology, training, branding and/or design from 2013 to 2015, and o otherwise. Apart from these variables, models control for size and sector. Relevance of R\&D or any of the other five investments for business growth can depend on characteristics of industry. In order to control for sector specific factors all four models include binary variables manufacturing (NACE category C), services (NACE categories H, I, J, K, L, M, $\mathrm{N}, \mathrm{R}$ ) and industry (NACE categories D, E, F). Reference sector is retail. 
Models also control for firm size measured in terms of number of employees. Binary variable sMEs takes value 1 if firm employs from 10 to 249 employees while large takes values 1 if firm has 250 and more employees. Reference size is micro firms, i.e. those employing less than 10 employees.

Overall sample includes responses from 11,434 micro, smes, and large firms operating in EU countries grouped in four categories according EIS methodology (For definitions see footnote iii). Firms who did not provide required information as well as those who did not know are excluded from ordered probit models. After clearing the dataset, model for modest innovators refers to 851 firms operating in Bulgaria and Romania. Sample of moderate innovators countries includes 5,639 firms from Croatia, Cyprus, the Czech Republic, Estonia, Greece, Hungary, Italy, Latvia, Lithuania, Malta, Poland, Portugal, Slovakia and Spain. 2,756 firms from Austria, Belgium, France, Ireland, Luxembourg and Slovenia are included in the model for strong innovators. And finally, model for lead innovators covers responses of 2,188 firms from Denmark, Finland, Germany, the Netherlands, Sweden and the United Kingdom.

\section{DESCRIPTIVE STATISTICS}

Descriptive statistics shows that presence of $\mathrm{R} \& \mathrm{D}$ investment varies between groups of countries (see table 1). As expected, it is the lowest in modest innovators (29.38 percent). Strong and lead innovators report similar level of engagement in $\mathrm{R} \& \mathrm{D}$, approximately 44 percent of firms in the sample.

The most prevalent in all groups of countries is investment in acquisition of technology. It is followed by investment in training and investment in branding. Design is more present in firms operating in lead and strong innovators countries. Descriptive statistics also shows that operating in modest innovators implies somewhat lower engagement in design activities. Investment in $\mathrm{R} \& \mathrm{D}$ appears to be the least implemented activity regardless of group of countries.

Cursory overview of descriptive statistics reveals that firms in analysed groups report different levels of involvement in these activities. It can be pointed out that presence of all five activities increases with the level of innovation performance (from modest to strong innovators). Descriptive statistics for lead innovators countries derogates this pattern. Compared to strong innovators countries, firms in lead innovators countries engage somewhat less in training, branding and $\mathrm{R} \& \mathrm{D}$ activities, but considering 
TAB LE 1 Descriptive Statistics: Percent of Firms that Report Investments in Three-Year Period

\begin{tabular}{lrrrr}
\hline Item & $(1)$ & $(2)$ & $(3)$ & $(4)$ \\
\hline Training & 66.63 & 72.55 & 79.93 & 78.38 \\
Branding & 59.46 & 61.66 & 73.40 & 72.25 \\
R\&D & 29.38 & 33.97 & 44.09 & 44.05 \\
Design & 45.48 & 47.26 & 54.43 & 61.38 \\
Acquisition of technology & 77.32 & 77.78 & 80.26 & 83.41 \\
\hline
\end{tabular}

NOTES Column headings are as follows: (1) modest innovators, (2) moderate innovators, (3) strong innovators, (4) lead innovators. Based on Eurobarometer data.

these differences are small we can conclude these are rather similar. They, however, do not follow different patterns. In all four groups of countries the highest percentage of firms reports investment in acquisition of technology, that is followed by investment in training, branding, design and $\mathrm{R} \& \mathrm{D}$ in that exact order.

Descriptive statistics on turnover change indicate that firms operating in countries that are strong and lead innovators have performed somewhat better from 2013 to 2015 (table 2). First, percentages of firms that faced turnover fall in analysed time-period are smaller. This is especially evident in percent of firms who experienced severe decline in their turnover (i.e. more than 25 percent). In those operating in countries with strong innovation performance as well as in those that lead in innovation performance less than 3 and less than 4 percent respectively report having turnover over 25 percent lower. According to data presented in table 2, percentage of firms whose turnover has fallen by more than 25 percent in moderate and modest innovators is over 7 percent. Furthermore, in $\mathrm{EU}$ countries that are leader in innovation performance nearly one half of firms in the sample has higher turnover than prior year 2013.

In general, firms in countries with better innovation performance are more engaged in all five activities and perform better. However, relying on descriptive statistics only we cannot conclude on importance of analysed activities for turnover change. These results show only the presence of these activities in firms across $\mathrm{EU}$ countries at different levels of innovation performance. The next step of the analysis focuses on exploring if engagement in these activities contributes to business performance. To do so, ordered probit is employed for four groups of countries (modest, moderate, strong and lead innovators). 
TAB LE 2 Descriptive Statistics: Turnover Trends in Three-Year Period

\begin{tabular}{lrrrr}
\hline Item & $(1)$ & $(2)$ & $(3)$ & $(4)$ \\
\hline Fallen more than 25\% & 7.29 & 7.28 & 2.86 & 3.68 \\
Fallen between 5\% and 25\% & 15.23 & 15.98 & 14.11 & 11.63 \\
Remained approximately the same & 37.11 & 35.80 & 37.44 & 34.86 \\
Risen between 5\% and 25\% & 30.03 & 31.31 & 35.77 & 34.14 \\
Risen more than 25\% & 10.34 & 9.62 & 9.82 & 15.69 \\
\hline
\end{tabular}

NOTES Column headings are as follows: (1) modest innovators, (2) moderate innovators, (3) strong innovators, (4) lead innovators. Based on Eurobarometer data.

\section{Results and Discussion}

Results of the ordered probit for modest, moderate, strong and lead innovators are presented in table 3. According to these results, firms in countries whose innovativeness is at modest level can improve their business performance only through engagement in training and acquisition of technology. Results of the ordered probit indicate that firms investing in these two activities are significantly more likely to achieve better business results. Not just investment in $\mathrm{R} \& \mathrm{D}$ but also investment in branding and design in these countries are not associated to improved business performance. This is somewhat expected considering lower level of innovativeness in these countries. It furthermore confirms importance of enhancing employees' knowledge and skills and need for catching-up with more developed economies by adopting state-of-the art technologies developed elsewhere.

According to the results of ordered probit, only firms operating in countries of strong innovativeness benefit from R\&D investment. Firms with $\mathrm{R} \& \mathrm{D}$ investment in these countries are more likely to have higher turnover in the short-run. Furthermore, in this case other analysed activities are significant sources of business growth. One possible explanation for this finding is in their continuous dedication to $\mathrm{R} \& \mathrm{D}$ and other activities. Deschryvere (2014) shows that R\&D growth and sales growth are possible only for firms that innovate continuously. Adequate balance and continuous dedication to these activities including R\&D is likely to lead to success in strong innovators countries.

Surprisingly, in lead innovators countries having invested in R\&D activities do not affect probability of turnover growth. The same is found for moderate innovators. Firms operating in these two groups of countries improve their business performance following the same pattern. Their 
TA B LE 3 Results of Ordered Probit for Modest, Moderate, Strong and Lead Innovators

\begin{tabular}{|c|c|c|c|c|}
\hline Item & (1) & (2) & (3) & (4) \\
\hline Training & $\begin{array}{c}0.232 \\
(0.087)^{\star * *}\end{array}$ & $\begin{array}{c}0.202 \\
(0.036)^{* * *}\end{array}$ & $\begin{array}{c}0.167 \\
(0.056)^{\star * *}\end{array}$ & $\begin{array}{c}0.212 \\
(0.062)^{* *}\end{array}$ \\
\hline Branding & $\begin{array}{r}0.043 \\
(0.089)\end{array}$ & $\begin{array}{c}0.182 \\
(0.033)^{* * *}\end{array}$ & $\begin{array}{c}0.149 \\
(0.050)^{\star * *}\end{array}$ & $\begin{array}{c}0.239 \\
(0.057)^{\star *}\end{array}$ \\
\hline $\mathrm{R} \& \mathrm{D}$ & $\begin{array}{r}0.045 \\
(0.092)\end{array}$ & $\begin{array}{r}0.001 \\
(0.034)\end{array}$ & $\begin{array}{c}0.115 \\
(0.047)^{* *}\end{array}$ & $\begin{array}{r}0.035 \\
(0.052)\end{array}$ \\
\hline Design & $\begin{array}{r}0.138 \\
(0.086)\end{array}$ & $\begin{array}{c}0.081 \\
(0.033)^{\star *}\end{array}$ & $\begin{array}{c}0.145 \\
(0.047)^{\star * *}\end{array}$ & $\begin{array}{c}0.129 \\
(0.054)^{\star *}\end{array}$ \\
\hline Acquisition of technology & $\begin{array}{c}0.313 \\
(0.095)^{* * *}\end{array}$ & $\begin{array}{c}0.306 \\
(0.037)^{* * *}\end{array}$ & $\begin{array}{c}0.180 \\
(0.054)^{* * *}\end{array}$ & $\begin{array}{c}0.137 \\
(0.064)^{* *}\end{array}$ \\
\hline Manufacturing & $\begin{array}{c}0.290 \\
(0.118)^{\star *}\end{array}$ & $\begin{array}{r}0.038 \\
(0.045)\end{array}$ & $\begin{array}{r}0.115 \\
(0.071)\end{array}$ & $\begin{array}{l}-0.126 \\
(0.084)\end{array}$ \\
\hline Services & $\begin{array}{r}0.128 \\
(0.086)\end{array}$ & $\begin{array}{r}0.055 \\
(0.033)^{\star}\end{array}$ & $\begin{array}{c}0.128 \\
(0.048)^{* * *}\end{array}$ & $\begin{array}{r}0.053 \\
(0.055)\end{array}$ \\
\hline Industry & $\begin{array}{l}-0.033 \\
(0.127)\end{array}$ & $\begin{array}{l}-0.048 \\
(0.045)\end{array}$ & $\begin{array}{r}0.070 \\
(0.066)\end{array}$ & $\begin{array}{r}0.036 \\
(0.075)\end{array}$ \\
\hline SME & $\begin{array}{c}0.201 \\
(0.082)^{\star *}\end{array}$ & $\begin{array}{c}0.200 \\
(0.031)^{* * *}\end{array}$ & $\begin{array}{c}0.122 \\
(0.045)^{\star * *}\end{array}$ & $\begin{array}{l}-0.006 \\
(0.050)\end{array}$ \\
\hline Large & $\begin{array}{r}0.264 \\
(0.176) \\
\end{array}$ & $\begin{array}{c}0.326 \\
(0.066)^{\star * *} \\
\end{array}$ & $\begin{array}{r}0.131 \\
(0.088) \\
\end{array}$ & $\begin{array}{l}-0.059 \\
(0.099) \\
\end{array}$ \\
\hline Number of analysed observations & 851 & 5639 & 2756 & 2188 \\
\hline $\operatorname{LR} \chi^{2}$ & 78.96 & 446.31 & 201.07 & 97.15 \\
\hline Prob $>\chi^{2}$ & 0.0000 & 0.000 & 0.000 & 0.000 \\
\hline Preudo $R^{2}$ & 0.0320 & 0.0274 & 0.0209 & 0.0158 \\
\hline
\end{tabular}

NOTES Column headings are as follows: (1) modest innovators, (2) moderate innovators, (3) strong innovators, (4) lead innovators. Based on Eurobarometer data.

turnover growth is enabled by investment in improving employees' skills, branding and acquisition of technology. While it is relatively easy to explain no relationship between $\mathrm{R} \& \mathrm{D}$ and business performance in countries whose innovativeness is at lower level, this finding for lead innovators model is more difficult to comprehend from the perspective of distance to frontier approach. One possible explanation is that most of the firms in lead innovators countries invest high amounts of money in complex R\&D projects and radical innovation development whose positive effects are not likely to occur in short-run. This can be also relevant for young firms who started their R\&D project in recent years. Improved 
business performance can be more evident in innovators with continuous engagement in $\mathrm{R} \& \mathrm{D}$, especially if their innovation portfolio consists of radical and incremental innovation projects. Extant findings show that the best effects are achieved by continuous involvement in both radical and incremental innovation projects (Sandvik and Sandvik 2003). Lack of significant relationship between $\mathrm{R} \& \mathrm{D}$ investment and business performance in lead innovators can be also related to their R\&D management and R\&D strategy, as well as various characteristics of their R\&D projects. Unfortunately, available data do not allow more detail analysis. At this point it can be concluded that the results clearly point to the nature of $\mathrm{R} \& \mathrm{D}$ projects for generating business growth.

As for investments in training, branding, design and acquisition of technology in firms operating in moderate, strong and lead innovators countries, they are all significant predictors of turnover growth. Firms that report investments in these activities in the three-year period are significantly more likely to report turnover growth. The findings testify that training and acquisition of new technologies are associated to turnover growth regardless of overall innovation performance of the country.

Research findings support the hypothesis on importance of $\mathrm{R} \& \mathrm{D}$ for business success at different levels of innovativeness. As expected, and in accordance with previous research findings, R\&D is not found relevant for turnover growth in firms operating in less innovative countries. The contribution of this analysis is in identifying other activities that lead to higher turnover growth. For firms in the countries at moderate level of innovation performance those include investment in training of employees, branding and reputation as well as acquisition of new technologies. Investment in design is found relevant for improving business growth at higher levels of innovativeness as well. The most puzzling finding that opens a venue for future research is the same pattern of growth in moderate and lead innovators.

As for the sector, models show that turnover growth is more likely in manufacturing firms in modest innovators and service sector in moderate and strong innovators. SMEs in all groups except in lead innovators were more prone to improve business performance. The same is relevant for large firms in countries that are moderate innovators. In other cases, sector and size variables are not significant.

The results in general show that $\mathrm{R} \& \mathrm{D}$ is not significant driver of business growth at lower levels of innovation development. Findings for lead innovators clearly reveal that relationship between $\mathrm{R} \& \mathrm{D}$ and business 
growth is rather complex and depends on the nature of the projects. As the available data did not enable us to explore this in more detail, this remains beyond the research scope. However, better insight into R\&D potential to induce business growth can be provided by analysing marginal effects after ordered probit. Marginal effects indicate how the decision to invest in R\&D (and other analysed activities) affects probability of turnover growth (or fall) in each category. For that purpose, focus is first on strong innovator as only in these countries $\mathrm{R} \& \mathrm{D}$ is significantly related to better business performance.

Marginal effects after probit for strong innovators models show that investment in $R \& D$ increases chances of having turnover growth between 5 and 25 percent by 2.6 percent. (Marginal affects after ordered probit available from the author on request). Turnover growth over 25 percent is 1.9 percent more likely if firm invests in $\mathrm{R} \& \mathrm{D}$. In comparison to other activities included in the analysis, R\&D investment contributes less to turnover growth. For instance, acquisition of new technology is associated with being 4.3 percent more likely to have turnover growth between 5 and 25 percent and 2.8 percent more likely of having an increase higher than 25 percent.

In fact, acquisition of technology, the only variable that is significant in all four models, is the most important contributor to turnover growth in modest, moderate and strong innovators countries. For modest innovators investment in acquisition of new technology increases likelihood of 5 to 25 percent turnover growth by 7 percent. It also increases chances of turnover growth over 25 by 4.3 percent. Firms in moderate innovators countries that acquire new technologies are 7.2 percent more likely to experience 5 to 25 percent turnover growth and 4.3 percent more likely of turnover growth higher than 25 percent.

Situation is somewhat different when it comes to lead innovators. Firms in these countries benefit the most (in terms of turnover growth) from investment in branding. It is associated with 4.2 percent of being more likely to grow 5 to 25 percent and 5.4 percent to grow more than 25 percent. Acquisition of technology contributes to turnover growth 2.4 percent and 3.1 percent, respectively.

\section{Concluding Remarks}

Results of this research confirm some of the previous empirical findings on importance of $\mathrm{R} \& \mathrm{D}$ for improving business performance at different levels of innovation performance and technological development. Firms 
in less innovative countries (countries further from technology frontier), but surprisingly also those at the top of innovation performance, will not benefit from $\mathrm{R} \& \mathrm{D}$. They are likely to improve their performance by investing in adoption of existing technology instead of investing in R\&D and development of new technologies. Extant findings indicate that investment in R\&D as well as its importance for generating growth will improve as the overall performance improves. The main point is how to improve overall development level to the point when investment in $\mathrm{R} \& \mathrm{D}$ starts generating growth. The findings in this paper contribute to the literature by identifying other activities (besides adoption of existing technology) that can help firms to improve their business results and build adequate innovation capabilities. This raises issue of not just quantity but also the quality of R\&D in firms in less innovative countries. If these activities are sporadic, not well-organized and adequately supported they will fail to contribute to business performance.

Depending on the level of innovativeness of the country, firms will benefit if they focus more effort and funds on other activities. Lower level of overall innovativeness in these countries indicates also lower pressure for firms to invest in R\&D, develop innovation and grow. For firms in countries at the lowest level on innovation performance investment in training and acquisition of technology is likely to give good impulse. Somewhat improved overall level of innovation performance makes also branding beneficial for generating higher turnover. Design investment becomes important for business growth at higher level of innovation performance. This is important finding for both managers of firms operating in respective countries as well as policy makers especially for those in countries aiming to improve innovation and overall performance. Too much effort on R\&D investment evidently will not pay in the environment that lags in terms of technological development and innovation performance. The focus should be on empowering growth by training and acquisition of technology as well as branding.

These findings reveal rather complex story behind innovation across EU countries. Building truly innovative society that rests on creativity and development of new technologies requires more than $\mathrm{R} \& \mathrm{D}$. For managers as well as policy makers in $\mathrm{EU}$ countries these findings provide useful input for innovation strategies and policies. Stronger emphasis should be on activities that ensure growth at the particular stage of innovation performance. This, however, does not mean that R\&D should be completely neglected and abandoned by firm operating in countries at lower 
level of innovation performance. It just indicates that gains from $R \& D$ in most of the cases will not be as high as expected. Investment in $R \& D$ is part of broader picture of growth (both business and economic) and has potential to contribute to success in other aspects.

These research results are also useful for understanding why innovation performance of some $\mathrm{EU}$ countries still lags despite efforts and measures designed to improve it. Measures that focus on R\&D only help firms to finance and carry on their innovative projects. However, these project in given circumstances will not result in improved business performance nor they will empower firms to continue their R\&D activities. Therefore, efforts should be made to support not just R\&D but also other activities relevant for generating higher turnover at given level of innovation performance.

One of the limitations of the study refers to the fact that data on investments in analysed activities and turnover growth refers to the same timeperiod. As in many studies on R\&D and firm performance, the problem of establishing temporal sequencing (Boulding and Staelin 1995) is present in this case. Concerning there is no time lag between investment and turnover, the results show immediate effects.

Models in this research include only binary variables (i.e. if firms invested in analysed activities or not). Likar, Kopač, and Fatur's (2014) research result show significant differences in $\mathrm{R} \& \mathrm{D}$ expenditures and business performance between innovation leaders and innovation followers. Therefore, interesting venue for future research is how the amounts of investment in any of the analysed activities influence business growth. It would be interesting to see if those that invest more in R\&D and other activities are able to grow more or even faster.

\section{Notes}

1 Distance from technology frontier has been first introduced in studies on innovation and productivity growth on country level (e.g. Acemoglu, Aghion, and Ziliboti 2006). However, the concept is equally applicable and often used in studies on firm level (e.g. Alder 2010; Gombau and Segarra, 2011).

$2 \mathrm{UK}$ included as the data refer to the time period when UK was EU member state.

3 The European Innovation Scoreboard (EIS) assess research and innovation performance of the EU Member States and selected countries. The analysis in this paper relies on 2017 edition of EIS. Indicators used in EIS 2017 refer to data for years 2014 to 2016. In EIS 2017 countries were grouped as 
follows: Modest Innovators - performance below 50\% of the EU average (Bulgaria and Romania), Moderate Innovators - performance between $50 \%$ and $90 \%$ of the Eu average (Croatia, Cyprus, the Czech Republic, Estonia, Greece, Hungary, Italy, Latvia, Lithuania, Malta, Poland, Portugal, Slovakia and Spain), Strong Innovators - performance between 90\% and $120 \%$ of the EU average (Austria, Belgium, France, Ireland, Luxembourg and Slovenia) and Innovation Leaders - performance is more than $20 \%$ above the Eu average (Denmark, Finland, Germany, the Netherlands, Sweden and the United Kingdom). More information on EIS methodology and innovation performance of $\mathrm{EU}$ member states is available on http: //ec.europa.eu/growth/industry/innovation/facts-figures/scoreboards_en.

4 Human capital defined as the stock of skills and knowledge possessed by an individual (Burgess 2016) is often associated to education level, namely formal education.

\section{References}

Aaker, D. A. 1992. 'Managing the Most Important Asset, Brand Equity' Planning Review 20 (5): 56-8.

Acemoglu, D., P. Aghion, P., and F. Zilibotti. 2006. 'Distance to Frontier, Selection, and Economic Growth.' Journal of the European Economic Association 4 (1): 37-74.

Alder, S. 2010. 'Competition and Innovation: Does Distance to Frontier Matter?' Center for Institutions, Policy and Culture in the Development Process Working Paper Paper 307, University of Zurich, Zurich.

Archibugi, D., and A. Filippetti. 2011. 'Is the Economic Crisis Impairing Convergence in Innovation Performance across Europe?' Journal of Common Market Studies 49 (6): 1153-82.

Autant-Bernard, C., S. Chalaye, F. Manca, R. Moreno, and J. Suriñach. 2010. 'Measuring the Adoption of Innovation: A Typology of E U Countries Based on the Innovation Survey.' Innovation 23 (3): 199-222.

Baldauf, A., K. S. Cravens, and G. Binder. 2003. 'Performance Consequences of Brand Equity Management: Evidence from Organizations in the Value Chain.' Journal of Product \& Brand Management 12 (4): 220-36.

Bartel, A. P., and F. R. Lichtenberg. 1987. 'The Comparative Advantage of Educated Workers in Implementing New Technology' The Review of Economics and Statistics 69 (1): 1-11.

Bloch, P. H. 1995. 'Seeking the Ideal Form: Product Design and Consumer Response.' Journal of Marketing 59 (3): 16-29.

Bond, S. R., and I. Guceri. 2017. 'R\&D and Productivity: Evidence from Large U K Establishments with Substantial R\&D Activities.' Economics of Innovation and New Technology 26 (1-2): 108-20. 
Boothby, D., A. Dufour, and J. Tang. 2010. 'Technology Adoption, Training and Productivity Performance.' Research Policy 39 (5): 650-61.

Boulding, W., and R. Staelin. 1995. 'Identifying Generalizable Effects of Strategic Actions on Firm Performance: The Case of Demand-Side Returns to R\&D Spending.' Marketing Science 14 (3): 222-36.

Burgess, S. 2016. 'Human Capital and Education: The State of the Art in the Economics of Education.' IZ A Discusion Paper 9885, Institute of Labor Economics, Bonn.

Cainelli, G., R. Evangelista, and M. Savona. 2006. 'Innovation and Economic Performance in Services: A Firm-level Analysis.' Cambridge Journal of Economics 30 (3): 435-58.

Cereda, M., G. Crespi, C. Criscuolo, and J. Haskel. 2005. 'Design and Company Performance: Evidence from the Community Innovation Survey'

Chauvin, K. W., and M. Hirschey. 1993. 'Advertising, R\&D Expenditures and the Market Value of the Firm.' Financial Management 22 (4): 12840.

Chen, P.-C., W.-C. Chan, S.-W. Hung, H.-J. Hsiang, and L.-C. Wu. 2016. 'Do R\&D Expenditures Matter More than Those of Marketing to Company Performance? The Moderating Role of Industry Characteristics and Investment Density.' Technology Analysis \& Strategic Management 28 (2): 205-16.

Chiva, R., and J. Alegre. 2009. 'Investment in Design and Firm Performance: The Mediating Role of Design Management.' Journal of Product Innovation Management 26 (4): 424-40.

Coad, A. 2008. 'Distance to Frontier and Appropriate Business Strategy' The Papers on Economics and Evolution 0807, Max-Planck-Institut für Ökonomik, Jena.

Coad, A., A. Segarra, and M. Teruel. 2016. 'Innovation and Firm Growth: Does Firm Age Play a Role?' Research Policy 45 (2): 387-400.

Cohen, W. M., and D. A. Levinthal. 1990. 'Absorptive Capacity: A New Perspective on Learning and Innovation.' Administrative Science Quarterly 35 (1): 128-52.

Cooper, R. G., and E. J. Kleinschmidt. 1987. 'An Investigation into the New Product Process: Steps, Deficiencies, and Impact.' Journal of Product Innovation Management 4 (3): 169-84.

Cuervo-Cazurra, A., and C. A. Un. 2010. 'Why Some Firms Never Invest in Formal R \& D.' Strategic Management Journal 31 (7): 759-79.

Dakhli, M., and D. De Clercq. 2004. 'Human Capital, Social Capital, and Innovation.' Entrepreneurship \& Regional Development 1 (2): 107-28.

Deschryvere, M. 2014. 'R \& D, Firm Growth and the Role of Innovation Persistence: An Analysis of Finnish smes and Large Firms.' Small Business Economics 43 (4): 767-85. 
D’Este, P., F. Rentocchini, and J. Vega-Jurado. 2014. 'The Role of Human Capital in Lowering the Barriers to Engaging in Innovation: Evidence from the Spanish Innovation Survey'. Industry and Innovation 21 (1): 1-19.

Ehie, I. C., and K. Olibe. 2010. 'The Effect of R\&D Investment on Firm Value: An Examination of us Manufacturing and Service Industries.' International Journal of Production Economics 128 (1): 127-35.

European Commission. 2016. 'Flash Eurobarometer 433: Innobarometer 2016 - E U Business Innovation Trends.' https://data.europa.eu/euodp/ sl/data/dataset/S2064_433_ENG

Filippetti, A., and A. Peyrache. 2013. 'Is the Convergence Party Over? Labour Productivity and the Technology Gap in Europe.' Journal of Common Market Studies 51 (6): 1006-22.

García-Quevedo, J., G. Pellegrino, and M. Vivarelli, M. 2014. 'R \& D Drivers and Age: Are Young Firms Different?' Research Policy 43 (9): 1544-56.

Goldin, C., and L. Katz. 2008. The Race between Education and Technology. Cambridge, m A: Harvard University Press.

Gombau, V., and A. Segarra-Blasco. 2011. 'The Innovation and Imitation Dichotomy in Spanish Firms: Do Absorptive Capacity and the Technological Frontier Matter?' Working Paper XREA P2011-22, Research Institute of Applied Economics, Barcelona.

Haber, S., and A. Reichel. 2007. 'The Cumulative Nature of the Entrepreneurial Process: The Contribution of Human Capital, Planning and Environment Resources to Small Venture Performance.' Journal of Business Venturing 22 (1): 119-45.

Hall, B. H., and B. Khan. 2003. 'Adoption of New Technology' Working Paper E03-330, University of California, Berkeley, cA.

Hall, B. H., and J. Mairesse. 1995. 'Exploring the Relationship between R \& D and Productivity in French Manufacturing Firms.' Journal of Econometrics 65 (1): 263-93.

Hall, B. H., J. Mairesse, and P. Mohnen. 2010. 'Measuring the Returns to $\mathrm{R} \& \mathrm{D}$.' In Handbook of the Economics of Innovation, edited by B. H. Hall and N. Rosenberg, 1033-82. Amsterdam: Elsevier.

Hirvonen, S., T. Laukkanen, and J. Salo. 2016. 'Does Brand Orientation Help в 2 в SMEs in Gaining Business Growth?' Journal of Business \& Industrial Marketing 31 (4): 472-87.

Homburg, C., M. Klarmann, and J. Schmitt. 2010. 'Brand Awareness in Business Markets: When Is It Related to Firm Performance?' International Journal of Research in Marketing 27 (3): 201-12.

Huggett, M., and S. Ospina. 2001. 'Does Productivity Growth Fall after the Adoption of New Technology?' Journal of Monetary Economics 48 (1): 173-95. 
Keller, K. L. 1993. 'Conceptualizing, Measuring, and managing CustomerBased Brand Equity.' Journal of Marketing 57 (1): 1-22.

Koellinger, P. 2008. 'The Relationship between Technology, Innovation, and Firm Performance - Empirical Evidence from E-Business in Europe.' Research Policy 37 (8): 1317-28.

Kotler, P., and G. A. Rath. 1984. 'Design: A Powerful but Neglected Strategic Tool.' Journal of Business Strategy 5 (2): 16-21.

Kravtsova, V., and S. Radosevic. 2012. 'Are Systems of Innovation in Eastern Europe Efficient?' Economic Systems 36 (1): 109-26.

Kutan, A. M., and T. M. Yigit. 2009. 'European Integration, Productivity Growth and Real Convergence: Evidence from the New Member States.' Economic Systems 33 (2): 127-37.

Leiponen, A. 2005. 'Skills and Innovation.' International Journal of Industrial Organization 23 (5-6): 303-23.

Likar, B., J. Kopač, and P. Fatur. 2014. 'Innovation Investment and Economic Performance in Transition Economies: Evidence from Slovenia.' Innovation: Organization \& Management 16 (1): 53-66.

Livesey, F., and J. Moultrie. 2009. Company Spending on Design: Exploratory Survey of UK Firms 2008. Cambridge: University of Cambridge.

Madsen, J. B., M. R. Islam, and J. B. Ang. 2010. 'Catching Up to the Technology Frontier: The Dichotomy between Innovation and Imitation.' Canadian Journal of Economics 43 (4): 1389-411.

Makrevska Disoska, E., D. Tevdovski, K. Toshevska-Trpchevska, and V. Stojkoski. 2018. 'Evidence of Innovation Performance in the Period of Economic Recovery in Europe.' Innovation 33 (3): 280-95.

Mansury, M. A., and J. H. Love. 2008. 'Innovation, Productivity and Growth in us Business Services: A Firm-level Analysis.' Technovation $28(1-2): 52-62$.

Minniti, M., and M. Lévesque. 2010. 'Entrepreneurial Types and Economic Growth.' Journal of Business Venturing 25 (3): 305-14.

Mohnen, P., and B. H. Hall. 2013. 'Innovation and Productivity: An Update.' Eurasian Business Review 3 (1): 47-65.

Munoz, T., and S. Kumar. 2004. 'Brand Metrics: Gauging and Linking Brands with Business Performance.' Brand Management 11 (5): 381-87.

Nevado, P. P., J. M. Barataa, and R. A. Almendra. 2016. 'Boosting Innovation and Growth through the Use of Design.' Journal of Business Economics and Management 17 (1): 74-91.

Perks, H., R. Cooper, and C. Jones. 2005. 'Characterizing the Role of Design in New Product Development: An Empirically Derived Taxonomy' Journal of Product Innovation Management 22 (2): 111-27. 
Piva, M., and M. Vivarelli. 2009. 'The Role of Skills as a Major Driver of Corporate R \& D.' International Journal of Manpower 30 (8): 835-52.

Roper, S., P. Micheli, J. H. Love, and P. Vahter. 2016. 'The Roles and Effectiveness of Design in New Product Development: A Study of Irish Manufacturers.' Research Policy 45 (1): 319-29.

Sandvik, I. L., and K. Sandvik. 2003. 'The Impact of Market Orientation on Product Innovativeness and Business Performance.' International Journal of Research in Marketing 20 (4): 355-76.

Segarra-Blasco, A., and M. Teruel-Carrizosa. 2008. 'Innovation Sources and Productivity in Catalonian Firms: A Quantile Regression Analysis.' Working Paper 2008-07, Research Institute of Applied Economics, Barcelona.

Siepel, J., M. Cowling, and A. Coad. 2015. 'Long-Run Drivers of Growth for u K High-Technology Firms.' In Entrepreneurial Growth: Individual, Firm, and Regio. Advances in Entrepreneurship, Firm Emergence and Growth, vol. 17, edited by A. C. Corbett, J. A. Katz, and A. Mckelvie, 95-126. Bingley: Emerald.

Unger, J. M., A. Rauch, M. Frese, and N. Rosenbusch. 2011. 'Human Capital and Entrepreneurial Success: A Meta-Analytical Review.' Journal of Business Venturing 26 (3): 341-58.

Vivarelli, M. 2014. 'Innovation, Employment and Skills in Advanced and Developing Countries: A Survey of Economic Literature.' Journal of Economic Issues 48 (1): 123-54.

Wong, H. Y., and B. Merrilees. 2008. 'The Performance Benefits of Being Brand-Oriented.' Journal of Product \& Brand Management 17 (6): 37283.

Yeung, M., and B. Ramasamy. 2008. 'Brand Value and Firm Performance Nexus: Further Empirical Evidence.' Brand Management 15 (5):322-35. 